\title{
Green space: A Luxury or a Necessity? Green Spaces in Condominium Sites in Sri Lanka
}

\author{
Nadeeka Jayaweera', a, Supun Rodrigo ${ }^{1, b}$, Jeyanthi Nadaraja ${ }^{1, ~ c,}$ \\ Upendra Rajapaksha ${ }^{1, d}$, Chathuri Jayasinghe ${ }^{2, e}$ \\ 1Department of Architecture, Faculty of Architecture, \\ University of Moratuwa, Sri Lanka \\ 2Department of Statistics, Faculty of Applied Sciences, \\ University of Jayawardenapura, \\ Sri Lanka \\ a njayaweera@uom.Ik, ${ }^{b}$ rodrigo.usn@gmail.com, ${ }^{c}$ jeneenadaraja@gmail.com, \\ d upendra@uom.lk, ${ }^{e}$ chathuri@s.jp.ac.lk
}

\begin{abstract}
Green spaces in cities have a positive impact on the health of the urban population. They decrease urban heat Island effects. Hence, green and open space should not be considered a luxury but an integral part of urban planning. However, the green spaces in Colombo city, Sri Lanka are declining at a rapid rate. Therefore this study investigates the reasons behind the decline of green space and high density housing developments in Colombo. Considered as a "green space" if the land cover has vegetation, the study found that $90 \%$ of small condominium developments (number of units ranging from 15 to 65) and 50\% of large condominium developments (over 65 units) had less than $1 \%$ of green space on site.

The reason for lack of green space was found to be high plot coverage, high FAR, small site extent and the absence of landscape, communal space and green buffer requirements in the current planning and building regulations for condominium developments.
\end{abstract}

Keywords: Condominium, green space, Sri Lanka, Planning, sustainability

\section{Introduction}

High density high-rise housing in Colombo can be attributed to high population growth, decrease in family size, growth in household income, rapid urbanization, scarcity of land and high land price, security, convenience and location (Ariyawansa and Udayanthika,2012).

In Sri Lanka, ownership of high-rise residential units, buildings and developments are regulated by the 1973 apartment ownership law and subsequent amendments by the act No. 45 of 1982, 4 of 1999 and 39 of 2003. In 2003, the Common Amenities Board was re-established as the Condominium Management Authority (CMA). The CMA regulates the ownership and Management Cooperations (MC's) of condominiums, although do not 
have any bearing on regulating the planning or building of condominiums. The Urban Development Authority (UDA) and the relevant municipal councils regulate planning and building of the residential developments.

The term condominium refers to a form of tenure, or a system of ownership in which owners have full title to the individual unit and a shared interest in the common areas of the property. The term "Condominium" is used in Sri Lanka, USA and Canada while in Australia such form of ownership is known as Strata title. Elsewhere, it is known by several other names including unit titles in New Zealand, coproprie'te' in France, and common hold in Britain (Dredge and Coiacetto,2011).

According to the data available at the CMA, 978 condominiums have been certified from 2006-2018. The commercial capital of Sri Lanka, Colombo city is where the highest number of high rise condominium constructions are taking place. Condominium living is an emerging trend in Sri Lanka as evident by the changing skyline in Colombo.

\section{Green space and psychological and physical health}

For the purpose of this study, green space refers to the amount of land cover with surface vegetation. Most research agrees that green space have beneficial health effects even though a strong causal effect is difficult to obtain due to confounding explanatory variables (Lee and Maheswaren, 2011; Ulmer et al, 2014; James et al, 2015). A study by Beyer et al (2014) in the United States concludes that higher levels of neighborhood green space were associated with significantly lower levels of symptomology for depression, anxiety and stress, after controlling for a wide range of confounding factors. The researchers conclude that 'greening' could be a potential mental health improvement strategy in the United States. Therefore green and open space should not be considered a luxury which only the wealthy can afford, but an integral part of urban planning (Maas et al, 2006).

In general, most people would agree that the view of a green space has psychological health benefits. Seresinhe et al (2015) have found that the inhabitants of more scenic environments report better health, across urban, suburban and rural areas, even when taking core socio-economic indicators of deprivation into account, such as income, employment and access to services. However, it is difficult to quantify the impact of intangible aspects such as views on human health. On the other hand, positive impact of natural views on residential market price is well-established (Gillard, 1981; Benson et al, 1998; Bourassa et al., 2003).

Overall, higher densities have many benefits in terms of efficient use of infrastructure, housing affordability, energy efficiency and possibly vibrant street life. But higher densities alone, like other built environmental features, do not appear to be the silver bullet in the public health campaign to increase physical activity (Forsyth et al, 2007). Outdoor green space is therefore an important component to a healthy balanced life.

\section{UHI effect and green cover in Colombo city and suburbs}

The higher degree of temperature in urban areas in comparison to the surrounds is termed the Urban Heat Island (UHI) effect. The megacities of developing countries in hothumid climate zones, where air conditioning is spreading very rapidly, are experiencing 
increasing urban heat island effects (Cheshmehzangi and Butters, 2015). One of the main causes of the UHI effect is the loss of green cover in cities. Surface Urban heat Island (SUHI) is observed based on land surface temperature. There are many negative impacts of SUHI, such as the weakening of living environments, elevation of ground-level ozone, an increased mortality rate, increased energy consumption, elevated emissions of air pollutants and greenhouse gases, impaired water quality, compromised human health and comfort increased hospitalization of the elderly and children, heat stress and death of the bird population, and heat stress in plants (Ranalage et al, 2017).

In the light of the health benefits of open and green space and the negative impact on the urban heat Island effect, the green cover of Colombo city needs to be increased. However, the green cover of Colombo city declined from $35.67 \%$ to $22.23 \%$ from 1956 to 2010 (Wickramasinghe et al, 2016). The study further revealed that the highest green cover $(49.65 \%)$ was reported in Narahenpita and only three other wards (Kirillipone, Cinnamon Gardens, and Thimbirigasyaya) had green cover over 30\% of the total land extent. In contrast, the green cover was less than $10 \%$ for ten wards, i.e., Kochchikade North, Kochchikade South, Grandpas North, Masangasweediya, Panchikawatte, Fort, Gintupitiya, New Bazaar, Maligawatte, and Aluthkade East. As a result of continuous reduction in green cover in Colombo, SUHI could increase. Ranalage et al, (2017) found indications of intensifying SUHI effects, especially during the 2007-2017 period when urbanization was more rapid.

Recent beautification of Colombo has had some positive impact on greenery. Ranalage et al (2017) has found indications of vegetation improvement in some parts of the CMA, especially from 2007 to 2017. However, in comparison to the loss of greenery, the improvements are minimal in Colombo and its suburbs.

Increasing greenery is a key feature for the image of the city, better health of citizens and mitigating the urban heat Island effect. Unfortunately, Colombo city and its suburbs have decreasing green coverage.

\section{Regulations affecting open and green space in urban areas}

The requirements of green space around a building in urban areas are governed by urban planning policies and regulations for the respective urban area. Urban planning and building regulations are not hard set rules. In building projects of national importance, exception from the rule can be obtained by relevant authorities. However such exceptions are generally granted taking in to account the benefits for the general public.

In Sri Lanka, the Urban Development Authority (UDA) is the national body for forming planning and building regulation for development of urban areas. For the purpose of this study, the following documents published by the UDA of Sri Lanka are reviewed.

- Planning and building regulations (General) published in 2015.

- Planning and building regulations 2008-2020

In concurrence to the planning and building regulations the development plans for the city of Colombo and its suburbs have also been gazetted by the government. For this study, the following development plans were considered. 
- The city of Colombo Development Plan 1999

- City of Colombo Development Plan (Amendment) 2008

- Dehiwala-Mount Lavinia Development Plan 2007-2020

- Jayawardenapura Kotte Development Plan 2007-2020

In order to better understand the impact of the local regulations on improving green space, the study reviews the Master Plan for the Western Region - 2030 and planning schemes of two international cities, Melbourne and Singapore. For the seventh year in a row, Melbourne was ranked as the most livable city in the world by the Economist Intelligence Unit. Singapore was ranked number one in Asia by ARCADIAS sustainable cities index for 2016 (ARCADIAS, 2016). Even though there are strong differences to the current Sri Lankan socio-economic context, valuable lessons could be learned by examining reasons for higher quality of living in these countries. For example, the Singapore Land Titles (Strata) Act is based on the Conveyance (Strata Titles) Act 1961 of New South Wales, Australia (Christudason, A., 2004) at a time there were significant socio-economic differences between the two nations. Singapore has benefitted immensely from such learning exercises. Therefore, a study of the desirable aspects of international cities could have positive impact on sustainable development of Sri Lankan cities.

\section{Master Plan for the Western Region - 2030}

The Ministry of Megapolis and Western Development has produced the Master Plan for the Western region - 2030. A draft was produced for Regulations and Guidelines for Planning, Zoning, Environmental and Building. The planning and building regulations pertaining to the Core Area in the Master Plan for the Western Region - 2030, is considered in this study as several improvements over current condominium development regulations were cited from this document.

\section{Planning scheme for the Melbourne city}

The planning scheme for the Melbourne city falls under the state of Victoria Department of Environment, Land, and Water \& Planning. It consists of maps, an ordinance and incorporated documents. The ordinance lays out the standards, schedules to the zones and other requirements to be met and the map identifies the geographical areas of zoning and overlays (such as heritage sites, significant vegetation or flood risk).

Condominium tenure type in Australia is termed Strata title. The physical units are known as units or apartments. The planning scheme refers to condominium tenure type development as apartment development. An apartment development of five or more storeys, excluding a basement, must meet the requirements of Clause 58 of the ordinance. Clause 58 covers a wide range of objectives that are of concern of present day high rise residential building construction.

\section{Development control parameters for residential development in Singapore}

Singapore is a well-planned city state, where land development is planned and strictly controlled (Yuen et al, 2006). The ability of the Urban Redevelopment Authority (URA) in making urban planning a tool for economic development in Singapore is irrefutable. Singapore has developed a unique housing system, with three-quarters of its 
housing stock being public housing develped by the Housing \& Development Board (HDB) (Phang and Helble, 2016). Condominiums are private developments controlled by the Handbook for Development control parameters for residential development and the Master Plan guides the urban development of Singapore. The residential sector in Singapore is categorized by registration instrument, density and housing type (URA, Oct 2017). Planning schemes and regulations are regularly updated by the relevant authorities. Therefore, this study refers to the document updated in October 2017.

The following planning tools were reviewed in the above regulations in order to develop the parameters for analyzing green space in condominiums in Colombo and its suburbs.

- Site extent

- Plot coverage

- Floor Area Ratio (FAR)

- Landscape

- Communal open to sky space at ground level

- Green buffer

\section{Site extent}

A large site has the capacity for a larger green space. The concept of condominium tenure in practical terms needs a large site to operate as it has to provide spacious common facilities for a large number of residents within a site. Therefore the minimum site extent for condominium development allowed by the planning regulations in a country determines that adequate space is available for the common facilities including green space.

The minimum site extent for condominium developments in Colombo is given in Form C1 in the City of Colombo Development Plan (Amendment) 2008 in relation to the road width, building lines and FAR. In planning and building regulations, 2008-2020, the site extent is given in Schedule 6 of Form C and Schedule 8 of form C. Development Plans also state a minimum site extent for zones. In Sri Lanka though high-rise condominiums are large scale buildings, they come up in very small sites because there is no minimum site extent given specifically for the development of condominiums. In Singapore, the minimum site extent specifically for condominium developments is $4000 \mathrm{~m}^{2}$ (URA, Oct 2017). In Colombo, a ten-storey condominium is allowed in sites of less than $1000 \mathrm{~m}^{2}$ if the road width is adequate.

\section{Plot coverage}

The percentage of total plinth area of a building in relation to the total land area of the plot is taken as the plot coverage of a building (UDA, 2008). The current planning regulations identify separate plot coverages for commercial and residential buildings. The maximum plot coverage for high-rise condominium developments ranges from $50 \%$ to $65 \%$ according to the height of the building in the local planning regulations. A similar term used in Singapore for plot coverage is site coverage. In Singapore, the maximum site coverage is $40 \%$ for Condominiums including covered car parks (URA, Oct 2017). Sri Lanka has 90 times the land cover of Singapore. Even though Singapore is a very small country, the government has committed to keeping $60 \%$ of the condominium development 
as un-built area. Low plot coverage ensures adequate green space for the residents while increasing the green cover.

\section{Floor Area Ratio (FAR)}

The gross floor area of all buildings on a lot divided by the area of such a lot is termed the Floor Area Ratio (UDA, 2008). The FAR for condominium development in the city of Colombo is given in Form C1 in the City of Colombo Development Plan (Amendment) 2008 in relation to the road width, building lines and the site extent. The equivalent term for FAR in Singapore is Gross Plot Ratio (GPR). The GPR of a site is the ratio of the gross floor area of a building(s) to the land area of the site. For planning purposes and as a general guide, GPR is given for various housing densities in Singapore as seen in the table below.

1. The guiding GPR is superseded by the GPR in the zoning regulations.

Table 1- Housing density in terms of GPR in Singapore (as a general guide)

\begin{tabular}{|l|c|}
\hline DENSITY & GPR \\
\hline Very High Density & $>2.8$ \\
\hline High Density & up to 2.8 \\
\hline Medium High Density & up to 2.1 \\
\hline Medium Density & up to 1.6 1.4 \\
\hline Low Density & (resultant from height) \\
\hline $\begin{array}{l}\text { Landed Housing (low } \\
\text { density) }\end{array}$ \\
\hline
\end{tabular}

Source: Urban Redevelopment Authority of Singapore. (2017). The handbook Development control parameters for residential development. Retrieved from

The maximum FAR for residential buildings in Colombo is very high in comparison to Singapore. There is an "unlimited" FAR for sites above $3500 \mathrm{~m}^{2}$ within Colombo and the suburbs. Sri Lanka in future will have continuous concrete masses in its cities with high FAR.

\section{Landscape}

Current local planning and building regulations do not have mandatory landscaping provisions. This has led to a neglect in landscaping in condominium complexes. In Melbourne City Planning Scheme, landscaping at the ground level is a mandatory requirement for apartments under clause 58. The following table gives the requirements for deep soil areas and canopy trees for high rise housing developments in Melbourne. 
Table 2: Deep soil areas and canopy trees in the Melbourne city planning scheme

\begin{tabular}{|c|l|l|}
\hline Site area & Deep soil areas (minimum) & \multicolumn{1}{c|}{ Tree provision } \\
\hline $\begin{array}{c}750- \\
1000 \mathrm{~m}^{2}\end{array}$ & $\begin{array}{l}5 \% \text { of site area } \\
\text { (minimum dimension of } 3 \mathrm{~m})\end{array}$ & $\begin{array}{l}1 \text { small tree }(6-8 \mathrm{~m}) \text { per } 30 \mathrm{~m}^{2} \text { of } \\
\text { deep soil }\end{array}$ \\
\hline $\begin{array}{c}1001- \\
1500 \mathrm{~m}^{2}\end{array}$ & $\begin{array}{l}\text { 7.5\% of site area } \\
\text { (minimum dimension of } 3 \mathrm{~m})\end{array}$ & $\begin{array}{l}1 \text { medium tree }(8-12 \mathrm{~m}) \text { per } 50 \mathrm{~m}^{2} \\
\text { of deep soil } \\
\text { Or } 1 \text { large tree per } 90 \mathrm{~m}^{2} \text { of deep } \\
\text { soil }\end{array}$ \\
\hline $1501-$ & $\begin{array}{l}10 \% \text { of site area } \\
(\text { minimum dimension of } 6 \mathrm{~m})\end{array}$ & $\begin{array}{l}1 \text { large tree (at least } 12 \mathrm{~m}) \text { per } 90 \\
\mathrm{~m}^{2} \text { of deep soil or } 2 \text { medium trees } \\
\text { per } 90 \mathrm{~m}^{2} \text { of deep soil }\end{array}$ \\
\hline $2500 \mathrm{~m}^{2}$ & $\begin{array}{l}1 \text { large tree (at least } 12 \mathrm{~m}) \text { per } 90 \\
\mathrm{~m}^{2} \text { of deep soil or } 2 \text { medium trees } \\
\text { per } 90 \mathrm{~m}^{2} \text { of deep soil }\end{array}$ \\
\hline $2500 \mathrm{~m}^{2}$ & $\begin{array}{l}15 \% \text { of site area } \\
(\text { minimum dimension of } 6 \mathrm{~m})\end{array}$ \\
\hline
\end{tabular}

Source: The Melbourne City Planning Scheme (2017).

Department of Environment, Land, Water and Planning, Victoria State Government.

Adhering to the provisions for landscape in table 2 will ensure a green Melbourne city for the present and future citizens of Melbourne.

In Singapore too the landscaping requirement takes a prominent place in the regulations. The provision for greenery in the condominium development is termed landscape replacement area policy. The new Landscape Replacement Area (LRA) requirements for non-landed residential developments of the URA of Singapore specifically target the provision of communal greenery and the levels of greenery provision will be tiered according to the development's intensity as shown in Table 3 .

Table 3: New Landscape Replacement Area requirements (LRA) for non-landed residential developments in Singapore

\begin{tabular}{|l|c|c|c|}
\hline $\begin{array}{l}\text { LRA requirements in non-landed Residential } \\
\text { developments }\end{array}$ & GPR $\leq 1.4$ & $\begin{array}{c}1.4<\mathrm{GPR}< \\
2.8\end{array}$ & GPR $\geq 2.8$ \\
\hline $\begin{array}{l}\text { Overall greenery provision } \\
\text { (as \% of site area) }\end{array}$ & 30 & 35 & 40 \\
\hline $\begin{array}{l}\text { On-ground greenery provision } \\
\text { (as \% of site area) }\end{array}$ & 20 & 30 & 35 \\
\hline
\end{tabular}

Source: Urban Redevelopment Authority of Singapore, (2017).

The handbook Development control parameters for residential development.

\section{Communal open-to-sky space at ground level}

There is no requirement for a communal open space at ground level for condominiums according to the current planning regulations. The CMA has requirements for common spaces but not particularly a requirement for a communal "open to sky space" at ground level in a Condominium, leading to many condominiums interpreting the 
concrete rooftop as the communal space. Green space can enhance the visual and functional aspects of the communal space for residents of condominiums.

The Melbourne City Planning Scheme requires under clause 58, for every high rise housing development with 40 or more units to provide a minimum area of communal open space of $2.5 \mathrm{~m}^{2}$ per unit or $250 \mathrm{~m}^{2}$, whichever is lesser.

The reason given by the URA in Singapore for the minimum site extent of $4000 \mathrm{~m}^{2}$ for condominiums is to provide generous provisions for communal and recreational facilities in a luxurious green setting. For small sites, there could be only space for one apartment block up to the allowable height, but with generous provision of communal and recreational facilities. However, there is no specific Communal Open Space (COS) requirement for condominium developments in Singapore.

\section{Green buffer}

Green buffer is a commonly used planning regulation in order to create a green barrier between the road and the building. In the draft - Megapolis Regulations and Guidelines - Planning, Zoning, Environmental and Building, the following green buffer is proposed for Colombo core area.

Table 4: Buffer requirements along roads for Colombo core area in the Megapolis Regulations and Guidelines

\begin{tabular}{|l|l|c|c|}
\hline Road Category & Proposed Use/Development1 & $\begin{array}{c}\text { Road Buffer } \\
\text { (minimum) }\end{array}$ & $\begin{array}{c}\text { Green } \\
\text { Buffer } \\
\text { (within } \\
\text { road buffer) }\end{array}$ \\
\hline Road Category A & $\begin{array}{l}\text { Residential/educational } \\
\text { (6 storeys or above) }\end{array}$ & $50 \mathrm{~m}$ & $5 \mathrm{~m}$ \\
\cline { 2 - 4 } & Residential/Educational (up to 5 storeys) & $24 \mathrm{~m}$ & $5 \mathrm{~m}$ \\
\cline { 2 - 4 } & $\begin{array}{l}\text { Commercial/Industrial/Institutional/Multi- } \\
\text { storey car park(MSCP)/Place of worship }\end{array}$ & $15 \mathrm{~m}$ & $5 \mathrm{~m}$ \\
\hline Road Category B & $\begin{array}{l}\text { Residential/Educational } \\
\text { (6 storeys or above) }\end{array}$ & $15 \mathrm{~m}$ & $5 \mathrm{~m}$ \\
\cline { 2 - 4 } & Residential/Educational (up to 5 storeys) & $12 \mathrm{~m}$ & $5 \mathrm{~m}$ \\
\cline { 2 - 4 } & $\begin{array}{l}\text { Commercial/Industrial/Institutional/Multi- } \\
\text { storey car park, Place of worship }\end{array}$ & $7.5 \mathrm{~m}$ & $3 \mathrm{~m}$ \\
\hline Road Category C & $\begin{array}{l}\text { Residential/Educational (6 storeys or } \\
\text { above) }\end{array}$ & $10 \mathrm{~m}$ & $3 \mathrm{~m}$ \\
\cline { 2 - 4 } & Residential/Educational (up to 5 storeys) & $7.5 \mathrm{~m}$ & $3 \mathrm{~m}$ \\
\cline { 2 - 4 } & $\begin{array}{l}\text { Commercial/Industrial/Institutional/Place } \\
\text { of worship }\end{array}$ & $5 \mathrm{~m}$ & $3 \mathrm{~m}$ \\
\hline Other Roads & Residential/ Educational & $7.5 \mathrm{~m}$ & $5 \mathrm{~m}$ \\
\cline { 2 - 4 } & $\begin{array}{l}\text { Commercial/Industry/Institution/Place of } \\
\text { Worship }\end{array}$ & & $3 \mathrm{~m}$ \\
\hline
\end{tabular}

Source: Western Region and Megapolis Planning Authority of Sri Lanka, Megapolis Regulations and Guidelines - Planning, Zoning, Environment and Building 
In Singapore, currently there is a regulation for the green buffer within the road buffer. All developments fronting a road in Singapore must observe a certain green buffer distance and building setback distance from the road. The buffer requirement depends on the hierarchy of the road, type of development and the building height. For residential developments, the buffer varies from $7.5 \mathrm{~m}$ to $30 \mathrm{~m}$ wide (URA, Oct 2017).

\section{Research Objectives}

This study assesses the green space within high-rise condominium development sites. The research focuses on the following three objectives.

1) Establish the parameters which impact green space in high-rise condominiums in the Sri Lankan context.

2) Investigate the impact of each parameter on green space within high-rise condominium developments.

3) Identify the parameters which decrease green space within Condominium developments.

\section{Methodology}

The study is conducted in the following phases depicted in Fig.1.

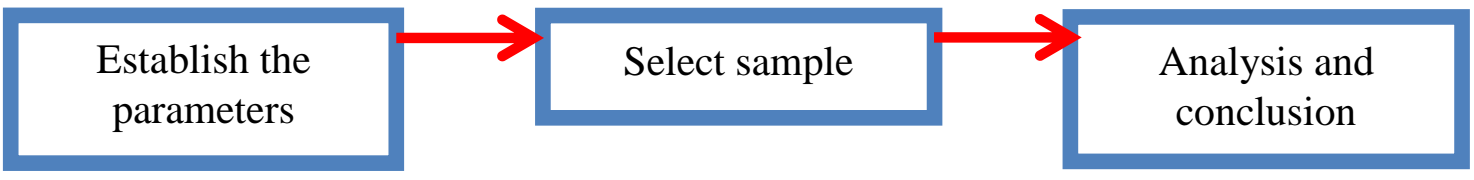

\section{Establishing the parameters}

Fig.1: Phases of the study

All 6 planning tools identified in the literature review are used as parameters of analysis in the study. At present only the site extent, plot coverage and FAR are enforced in the current regulations for condominium developments in Sri Lanka. Landscape, communal open to sky space at ground level and green buffer do not make part of the current local regulations.

\section{Sample selection for the survey of green space}

This study was a joint project by the Condominium Management Authority (CMA) of Sri Lanka and the Department of Architecture of the University of Moratuwa, Sri Lanka in order to investigate the impact of condominium developments on sustainability. The preliminary data set for this study was obtained from the CMA database. The Colombo city and its suburbs were selected as the geographical area of the study as most condominiums are constructed within this area.

For the purpose of this study, condominiums with over 15 units were considered as high rise condominiums as they are likely to have ground plus four floors. 238 private high rise condominiums with over 15 units in the Colombo city and its suburbs certified from 2005- 2016 were taken as the sample for this study. From the 238 condominiums it was noted that close to $90 \%$ of condominiums had between 15-65 units while close to $10 \%$ had over 65 units as seen in Fig. 2. 212 certified condominiums had between 15 and 65 units. It was also noted that these condominiums had similar compact forms. Therefore, 24 case studies from condominiums with units ranging from 15-65 were randomly selected for the study while 7 case studies were obtained by convenient sampling. 


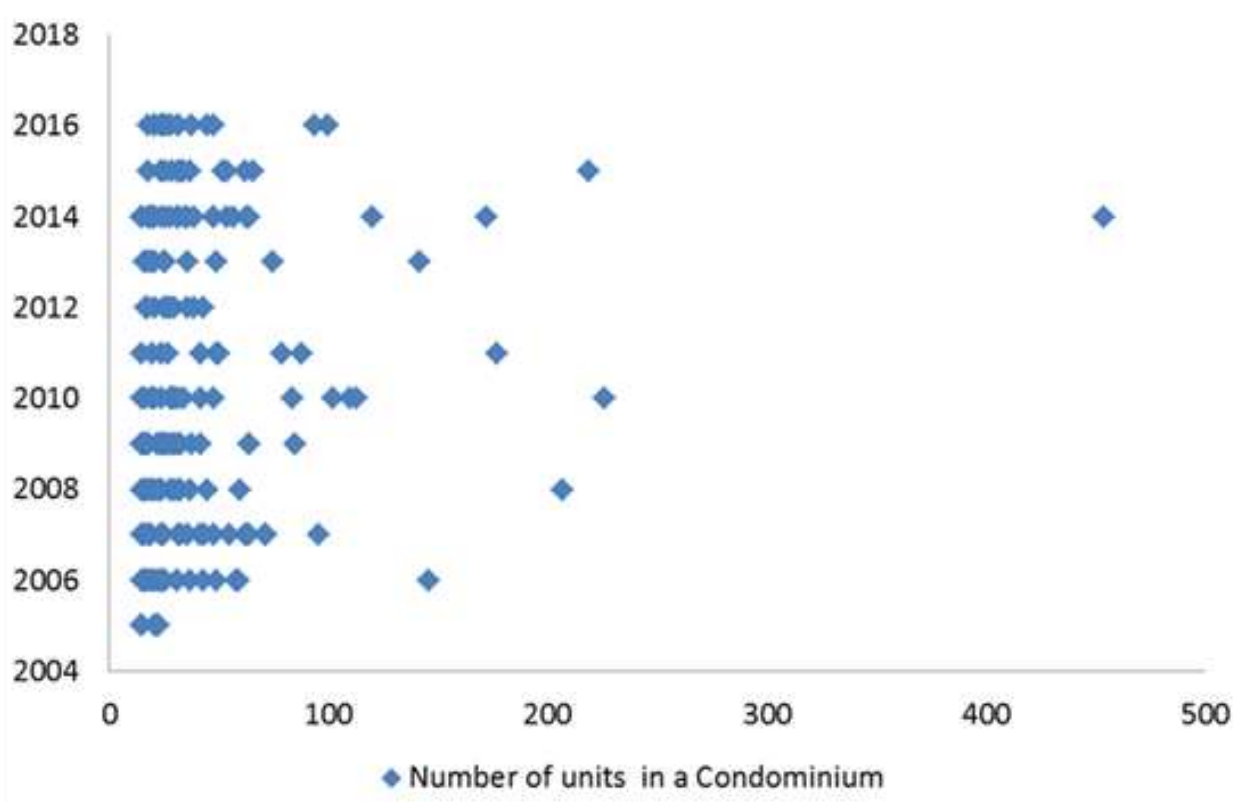

Fig.2: Number of units in high-rise condominiums 2005-2016

Source: Authors

26 Condominiums with 65 units or above have received certification by CMA. Therefore, all 26 condominiums with units over 65 were selected for the survey as they had much more variability in building form.

The analysis is conducted separately for small condominium developments (number of units between 15 and 65) and large condominium developments (number of units over 65). Table 5 consists of the minimum, maximum and median of number of units, number of floors and site extent of the condominium developments in the study. Condominiums within one site were considered as a single condominium complex for the purpose of this study.

Council approved plans of all 57 condominiums in the survey were requested from the respective condominium managers and developers. Green space, FAR, plot ratio and the site extent of 11 small condominium developments (15-65units) and 10 large condominium developments (over 65units) were calculated using the council approved plans obtained in the survey.

Table 5: Sample statistics

\begin{tabular}{|c|c|c|c|c|}
\hline & & Min. & Max. & Median \\
\hline \multirow{3}{*}{$\begin{array}{c}\text { Small Condominium } \\
\text { developments } \\
\text { (number of units } \\
\text { between } 15 \text { and 65) }\end{array}$} & Units & 16 & 48 & 32 \\
\hline & Floors & 6 & 10 & 9 \\
\hline & Site extent & $412 m^{2}$ & $1122 \mathrm{~m}^{2}$ & $689 \mathrm{~m}^{2}$ \\
\hline \multirow{3}{*}{$\begin{array}{c}\text { Large Condominium } \\
\text { developments } \\
\text { (number of units over 65) }\end{array}$} & Units & 66 & 420 & 142 \\
\hline & Floors & 11 & 38 & 16 \\
\hline & Site extent & $1044 \mathrm{~m}^{2}$ & $66759 \mathrm{~m}^{2}$ & $5523 \mathrm{~m}^{2}$ \\
\hline
\end{tabular}




\section{Analysis}

The green space for the study was calculated as a percentage of the site extent. The green space at any level was divided by the site extent and presented as a percentage. $90 \%$ of small condominium developments have less than $1 \%$ green space while $50 \%$ of large condominiums have less than $1 \%$ green space. Therefore a lack of green space is identified mostly in small condominium developments (number of units between 15 to 65 units) in the study (Fig.3).

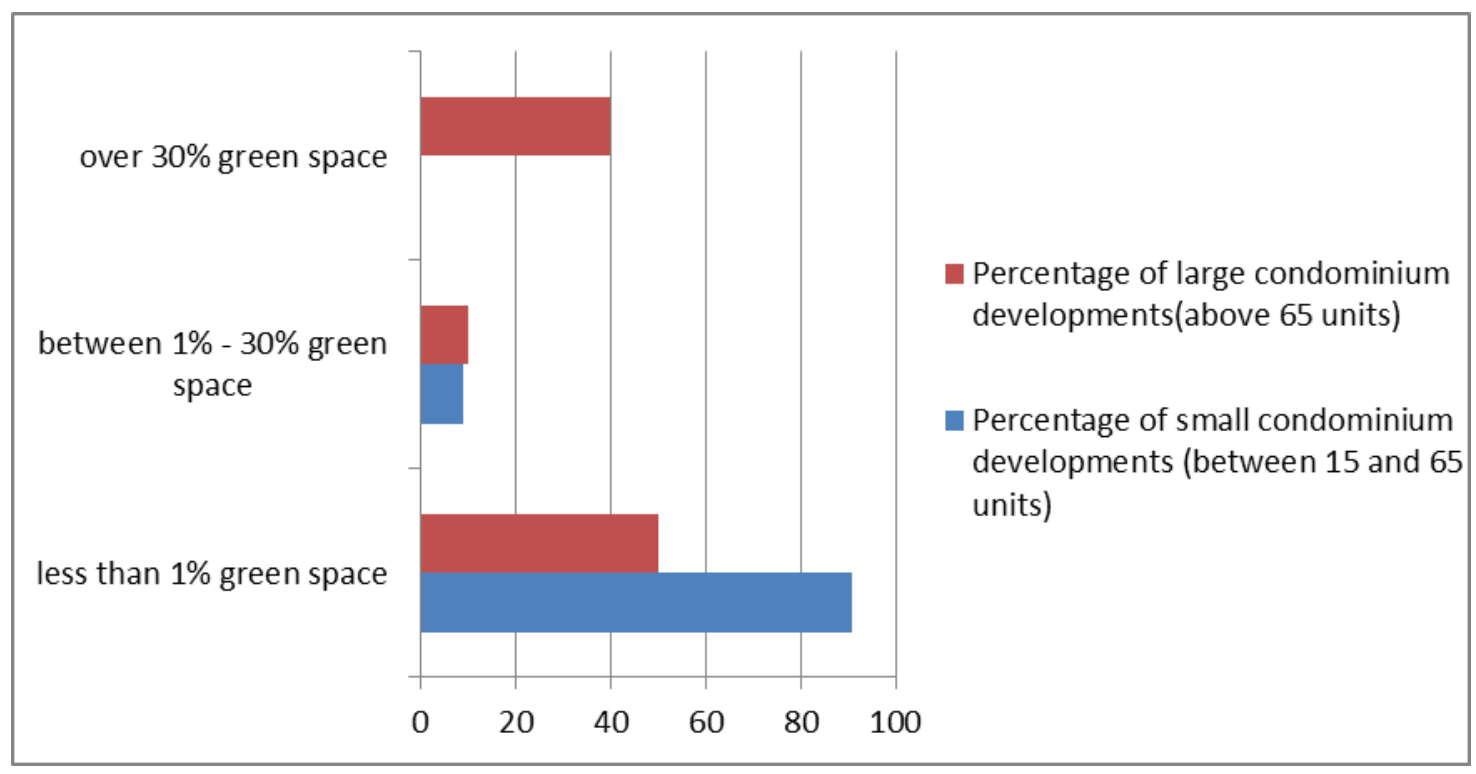

Fig. 3: Green space within condominium developments in the study

Source: Authors

\section{Site extent}

For the purpose of analyzing site extents, the data were grouped into three categories. Sites below $2000 \mathrm{~m}^{2}$, sites between $2000-4000 \mathrm{~m}^{2}$ and sites above $4000 \mathrm{~m}^{2}$. It is clear from the Fig. 4 that sites of less than $2000 \mathrm{~m}^{2}$ lacks green space. Sites of over 4000 $\mathrm{m}^{2}$ had a higher percentage of green space in large condominium developments. Therefore large sites have a positive impact on increasing green space in condominiums while small sites had a negative impact in the study. 


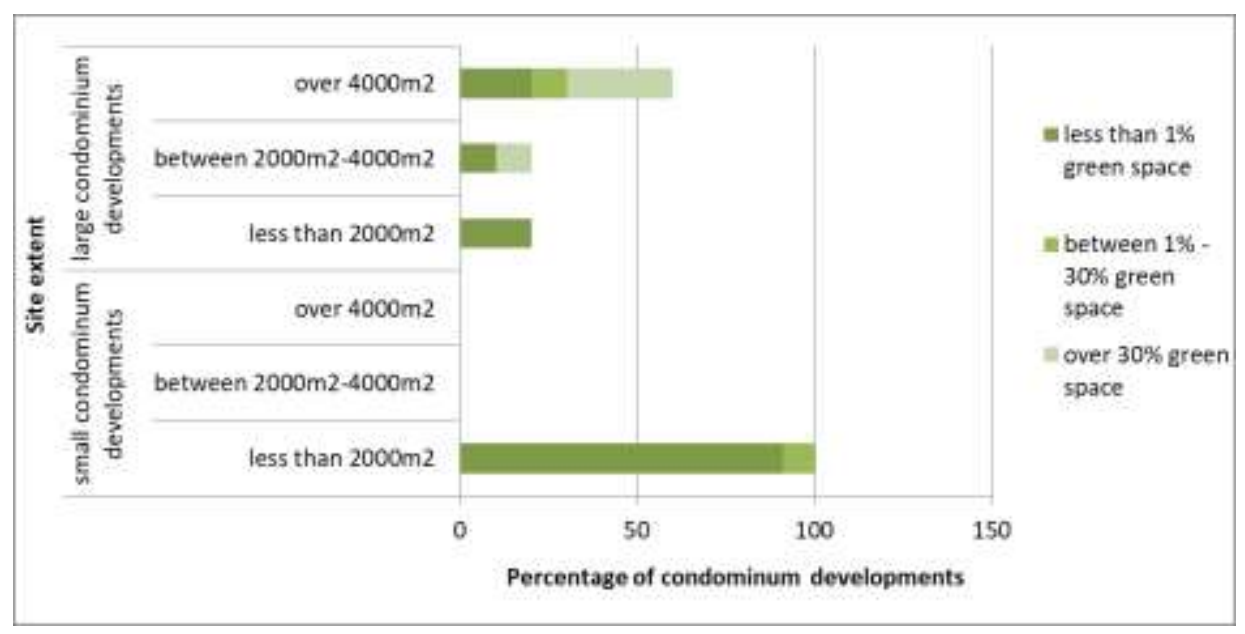

Fig. 4: Impact of site extent on green space in high rise condominium developments Source: Authors

Even though there are opportunities for allocating more green space in large sites, the current trend of site extent for condominium developments are less than $2000 \mathrm{~m}^{2}$. A closer investigation of building plans confirmed that condominiums of as much as 7 floors have been constructed in plots less than $500 \mathrm{~m}^{2}$. Condominiums in practical terms are large scale development projects. In small sites adequate open and green space cannot be provided for the benefit of the residents. Therefore a minimum site extent that can accommodate all needs of the residents including green space is required for condominium development sites in planning zones that are not designated to be highly commercialized.

\section{Plot coverage}

Local planning regulations limit residential developments to a maximum plot coverage between $50 \%$ and $65 \%$ based on the number of floors, road frontage and open space. However, some condominiums in the study had plot coverage of over $65 \%$. A closer investigation of building plans confirmed that some condominiums had over $80 \%$ plot coverage. 


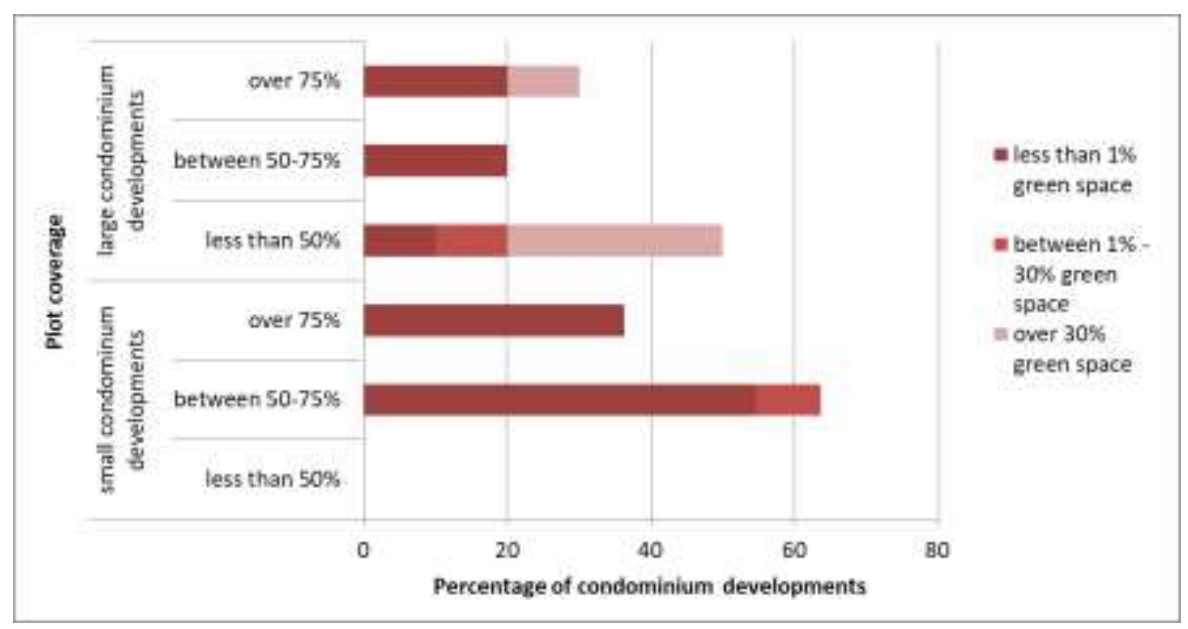

Fig. 5: Impact of plot coverage on green space in high rise condominiums

Source: Authors

It is clear that the high plot coverage reduces green space on site as per Fig.5. According to Fig.5, plot coverage of less than $50 \%$ is conducive for establishing green space of over $30 \%$ on site in large condominium developments. A very high plot coverage has resulted in a continuous mass of concrete buildings in areas such as Wellwatte and Dehiwela. A similar trend was also observed in Nugegoda and Nawala.

\section{Floor Area Ratio (FAR)}

High FARs for residential developments in the Colombo city and its suburbs were observed. According to Fig.6, large condominium developments with an FAR of less than $1: 3$ had more than $30 \%$ green space. $90 \%$ of small condominiums with an FAR of over 1:3 had less than 1\% green space. Therefore in this study a low FAR is conducive to more green space. However due to very high FAR values, Colombo is looking at compact masses of concrete without any greenery on site.

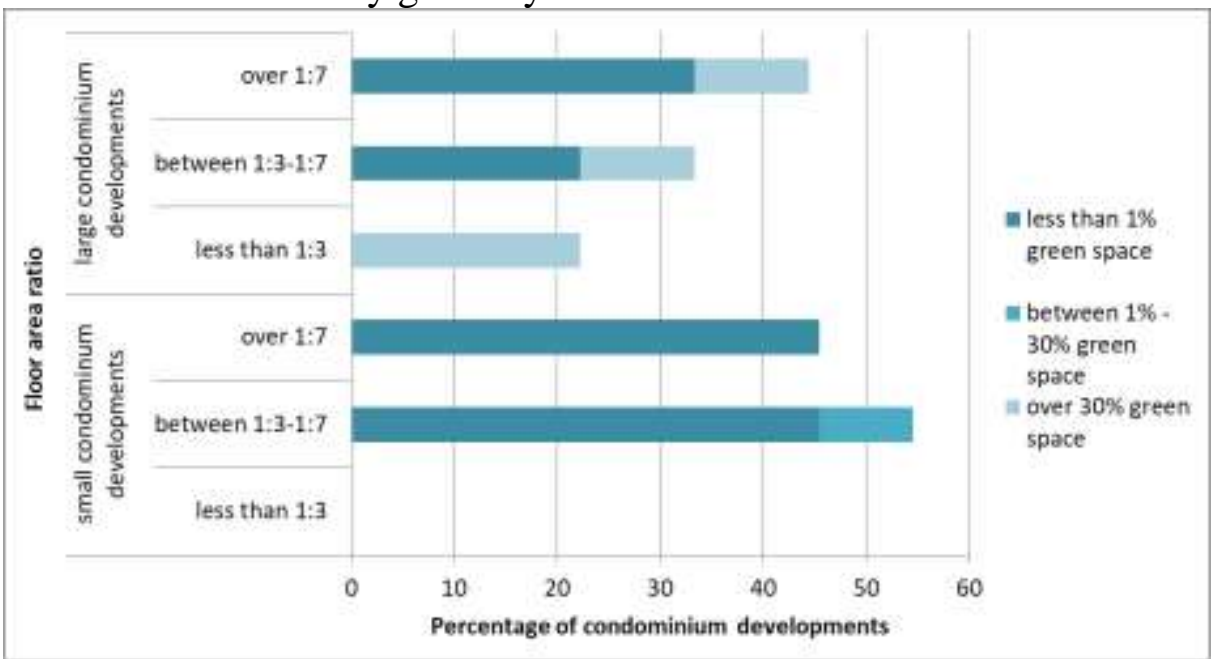

Fig.6: Impact of FAR on green space in high rise condominium developments* Source: Authors 


\section{Landscape}

$90 \%$ of small condominium developments (number of units ranging from 15 to 65) and $50 \%$ of large condominium developments (with over 65 units) had less than $1 \%$ of green space on site. Lack of landscape requirement in regulations has resulted in ground floor area been fully developed as a car park in most small condominium developments. Urban areas are developed as concrete landscapes, with inadequate greenery despite the country being located in a tropical zone and has much potential to be developed as a green city. The need for a regulation for landscaping within the site is essential for the sustainability of Colombo city.

\section{Communal space at ground level}

Most condominiums are interpreting the communal space as the roof top. In the local climate rooftops can only be accessed during the night time due to the hot climate during the day. Some swimming pools are also difficult to use due to windy conditions being located at higher levels. Due to lack of green space, young children living in most condominiums in the study are deprived of any connection to nature.

\section{Green buffer}

Building up to the road edge is allowed in selected urban areas in international cities due to highly concentrated commercial activities. In Sri Lanka, building up to the road edge is visible in many cities and even suburbs that are not highly commercialized. In the context of condominium developments, a green buffer within a road buffer can ensure pedestrian friendly roads. Fig.7 illustrates how green buffer regulation creates walkalbe paths.

In Sri Lanka many B and C class roads have no pedestrian walk ways due to lack of road buffer and green buffer.

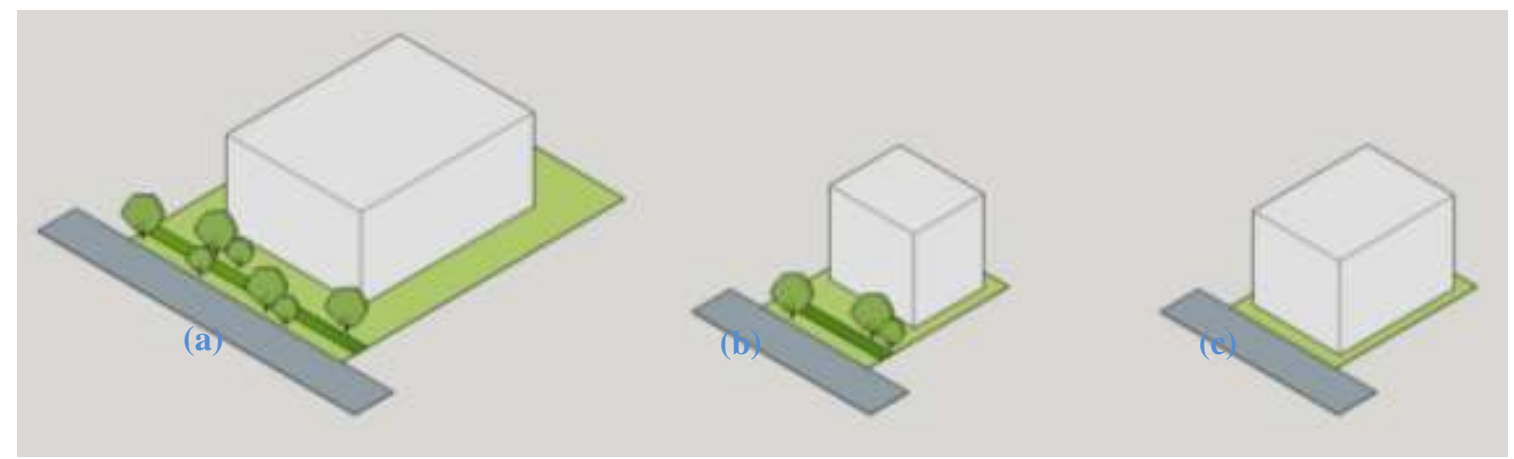

(a) Road buffer and green buffer for an "A" category road in Singapore on a site extent of $4000 \mathrm{~m}^{2}$.

(b) Road buffer and green buffer proposed for residential buildings above 6 floors on " $A$ " class roads on a site extent of $1000 \mathrm{~m}^{2}$ by the WRMP 2030. **

(c) Front space requirement for an 8 storey residential building on a site extent of $1000 \mathrm{~m}^{2}$ according to schedule 6-form C in the Planning and Building regulations - 2008-2020.

*Source: https://www.ura.gov.sg/uol/publications/technical/dc-handbooks/dcparameters-for-residential-development Accessed on 27/10/2017.

**Source: Megapolis regulations and guidelines- https://megapolis.gov.lk/downloads/ Accessed on 27/10/2017.

Fig.7: Illustrated green buffer regulations 


\section{Conclusion}

The lack of green space in condominium developments in Sri Lanka is highly visible in Colombo and its suburbs. This study documents the lack of green space and establishes its causes. In the study, all small condominiums had a site extent of less than $2000 \mathrm{~m}^{2}$. This has resulted in $90 \%$ of the small condominiums having less than $1 \%$ green space. Establishing a minimum site extent to accommodate adequate green space, in planning zones which are not designated to be highly commercialized, is the first step in steering condominium developments towards increasing onsite greenery.

The lack of conformity to the plot coverage regulation is clear in the study where some condominiums had over $80 \%$ plot coverage. Singapore and Melbourne has very strict enforcement of its regulations that protects the rights to green space. Green and open space should not be considered a luxury which only the wealthy can afford, but an integral part of urban planning (Maas et al, 2006). However trends in condominium developments in this study points towards green space becoming available only for residents of large condominiums in Colombo. New regulations such as requirement for landscape, communal open space and green buffer needs to be established in order to make condominium developments livable for its residents as well as contribute to well-being of the society rather than become a problematic case of high rise urban sprawl.

There is an urgent need to update current regulations for site extent, plot coverage, FAR, and introduce new regulations for landscape, communal open to sky space and green buffer for sustainable condominium development in Sri Lanka.

\section{Further research}

This study is limited to analyzing five parameters within a small data set. For further research using software such as Geographical Information Systems (GIS) a more expansive study for a large data set could be conducted for a wider number of parameters.

\section{Acknowledgement}

The authors would like to thank the Chairman of the Condominium Management Authority, Mr.C.A. Wijeyeweere and the staff members of the CMA for their contribution to this study. We would also like to thank the condominium managers and developers who provided data for the study. The study was funded by the Senate Research Council of the University of Moratuwa, through the National Development Grant -SRC/ND/01/2017.

\section{References}

ARCADIS. (2016). Sustainable cities Index: 2016. Retrieved from https://www.arcadis.com/media/0/6/6/\%7B06687980-3179-47AD-89FDF6AFA76EBB73\%7DSustainable\%20Cities\%20Index\%202016\%20Global\%20Web.pdf

Ariyawansa, R.G, \& Udayanthika, A. G. P. I. (2012). Living in high-rise: An analysis of demand for condominium properties in Colombo, International Journal of Sociology and Anthropology Vol. 4(1), pp. 31-37

Benson, E.D., Hansen, J.L., and Schwartz, A.L. (1998) . The Journal of Real Estate Finance and Economics, 16: 55. https://doi.org/10.1023/A:1007785315925

Bertaud, A. and Malpezzi, S. (2001). Measuring the costs and benefits of urban land use regulation: a simple model with an application to Malaysia. Journal of Housing Economics 10 (3), 393-418 
Beyer K.M., Kaltenbach A, Szabo A, Bogar S, Nieto F.J, and Malecki K.M.(2014). Exposure to neighborhood green space and mental health: evidence from the survey of the health of Wisconsin. Int J Environ Res Public Health. 2014;11(3):3453-72.

Bourassa, S.C., Hoesli, M.,and Sun, J. (2003). What's in a View? Environment and Planning A: Economy and Space, 36, 8, 1427 - 1450. Retrieved from SSRN: https://ssrn.com/abstract=410729 or http://dx.doi.org/10.2139/ssrn.410729

Chan, E.H.W. and Lee, G.K.L. (2009).Design considerations for environmental sustainability in high density development: a case study of Hong Kong, Environment, Development and Sustainability. 11, 2, 359-374. https://doi.org/10.1007/s10668-007-9117-0

Christudason, A. (2004).Private sector housing redevelopment in Singapore: A review of the effectiveness of radical strata title legislation, ENHR Conference, Cambridge, UK available at file://C:/Users/win\%2010/Desktop/10.1.1.202.8348.pdf

Cheshmehzangi A. and Butters C. (2015). Sustainable Living and Urban Density: The Choices are Wide Open, Energy Proceedia,88.

Department of Environment, Land, Water and Planning, Victoria State Government. (2017).The Melbourne city planning scheme retrieved from http://planningschemes.dpcd.vic.gov.au/schemes/melbourne. Accessed on 27/10/2017.

Dredge D. and Coiacetto E. (2011). Strata Title: Towards a Research Agenda for Informed Planning Practice, Planning Practice and Research, 26:4, 417-433, DOI:10.1080/02697459.2011.582383

Forsyth A.,Oakes M., Schmitz K.H. and Hearst, M.(2007). Does Residential Density Increase Walking and Other Physical Activity?Urban Studies, 44, 4, 679 - 697.

Gillard, Q. (1981). The Effect of Environmental Amenities on House Values: The Example of a View Lot, Professional Geographer 33 (May), 216-220.

James, P., Banay, R.F. and Hart, J.E. (2015). A Review of the Health Benefits of Greenness. Current Epidemiology Reports (2015) 2: 131. https://doi.org/10.1007/s40471-015-0043-7

Lee, A.C. and Maheswaran, R. (2011). The health benefits of urban green spaces: a review of the evidence. J Public Health (Oxf). Jun;33(2):212-22.

Maas, J., Verheij, R. A., Groenewegen, P. P., de Vries, S., and Spreeuwenberg, P. (2006). Green space, urbanity, and health: how strong is the relation? Journal of Epidemiology and Community Health, 60(7), 587-592. http://doi.org/10.1136/jech.2005.043125

Ministry of Megapolis and Western Development, Western Region and Megapolis Master plan 2030. Retrieved from https://megapolis.gov.lk/downloads/ on 01.12.2017

Phang, S. Y., and Helble .M. (2016). Housing Policies in Singapore. ADBI Working Paper 559. Tokyo: Asian Development Bank Institute. Available: http://www.adb.org/publications/housing-policies-singapore/

Ranagalage, M.; Estoque, R.C. and Murayama, Y. (2017). An Urban Heat Island Study of the Colombo Metropolitan Area, Sri Lanka, Based on Landsat Data (1997-2017). ISPRS Int. J. Geo-Inf. 2017, 6, 189.

Seresinhe C.I, Preis, T. and Moat, H.S. (2015). Quantifying the Impact of Scenic Environments on Health, Scientific reports retrieved from https://www.nature.com/articles/srep16899

Ulmer J.M., Chapman J.E., Kershaw S.E., Campbell M. and Frank L.D. (2014). Application of an evidence-based tool to evaluate health impacts of changes to the built environment. Can J Public Health. 2014 Jul 11;106(1 Suppl 1):eS26-34. doi: 10.17269/cjph.106.4338.

United Nations, Department of Economic and Social Affairs, Population Division. (2014). World Urbanization Prospects: The 2014 Revision, Highlights (ST/ESA/SER.A/352).

Urban Development Authority. (1999). City of Colombo Development Plan-1999

Urban Development Authority. (2008). Development plan for the Dehiwela-Mount Lavinia Municipal Council area 
Urban Development Authority. (2008). Development plan for the Sri Jayawardenapura-Kotte Municipal Council area

Urban Development Authority. (2008).City of Colombo Development Plan (Amendment)-2008

Urban Development Authority. (2015).Planning and building regulations (General)

Urban Development Authority. Planning and Building regualtions-2008-2020

Urban Redevelopment Authority of Singapore. (2017). The handbook Development control parameters for residential development. Retrieved from

https://www.ura.gov.sg/uol/publications/technical/dc-handbooks. Accessed on 27/10/2017.

Western Region and Megapolis Planning Authority of Sri Lanka, Megapolis Regulations and Guidelines - Planning, Zoning, Environmental and Building Draft retrieved from https://megapolis.gov.lk/downloads/. Accessed on 27/10/2017.

Wickramasinghe, L., Subasinghe, U.and Ranwala, S. (2016). Spatial and temporal changes of the green cover of Colombo city in Sri Lanka from 1956 to 2010. Journal of Environmental Professionals Sri Lanka. 5. 53. 10.4038/jepsl.v5i1.7868.

World Bank. (2009). Reshaping Economic Geography. Retrieved from http://documents.worldbank.org/curated/en/730971468139804495/pdf/437380REVISED0 1BLIC1097808213760720.pdf. Accessed on 01.12.2017

Yuen, B, Yeh, A. and Appold, S.J. (2006). High-rise Living in Singapore Public Housing, Urban Studies, 43, 3

https://www.ura.gov.sg/uol/publications/technical/dc-handbooks. Accessed on 27/10/2017. http://planningschemes.dpcd.vic.gov.au/schemes/melbourne. Accessed on 27/10/2017. https://www.ura.gov.sg/uol/publications/technical/dc-handbooks. Accessed on 27/10/2017. Draft retrieved from https://megapolis.gov.lk/downloads/. Accessed on 27/10/2017. 